\title{
THE SYSTEMATIC POSITION OF THE WATER REDSTARTS, CHAIMARRORNIS AND RHYACORNIS
}

The generic position of the water redstarts is controversial. Recent faunistic books assign the three species to two genera: the White-capped Water Redstart Chaimarrornis leucocephala, the Plumbeous Water Redstart Rhyacornis fuliginosus and the Philippine Water Redstart R. bicolor (Ali \& Ripley 1973a,b, du Pont 1971). Previously, Hartert (1910) included Rhyacornis in Chaimarrornis, and Ripley (1952) united both genera with Phoenicurus (cf. Vaurie 1955). Goodwin (1957), however, suggested that the water redstarts were allied to Oenanthe, Saxicola and Saxicoloides, and that the resemblances between Chaimarrornis and Rhyacornis were the result of convergence. These views were adopted by Ripley (1962), who subsequently (1964) placed Rhyacornis between Phoenicurus and Hodgsonius and Chaimarrornis between Oenanthe and Saxicoloides. Desfayes (1969) included the White-capped Water Redstart in the otherwise African genus Thamnolaea, and allied Rhyacornis spp. with Oenanthe, particularly the Red-tailed Wheatear $O$. xanthoprymna. Hall \& Moreau (1970) have merged Thamnolaea with Myrmecocichla, but the expanded genus is still confined to Africa except for the species leucocephala.

This paper reviews the reclassifications of Goodwin (1957) and Desfayes (1969). I made brief observations of White-capped and Plumbeous Water Redstarts during a visit to Kashmir and Nepal in April 1973. Plumage characters were studied on skins at the University of Michigan, Ann Arbor, and Royal Ontario Museum, Toronto.

\section{OBSERVATIONS}

Size

Wing measurements presented by Desfayes (1969) to show similarity in size between the White-capped Water Redstart and Thamnolaea spp. indicate little overlap. The White-capped is larger than most species of Phoenicurus (but smaller than Güldenstädt's Redstart P. erythrogaster), and has tarsi and tail long compared with Phoenicurus spp.,

\section{TABLE 1}

Plumage characteristics among some genera of thrushes. Except for the last category all comparisons refer to the adult male plumage only. + denotes present, \pm present in some species, -- absent

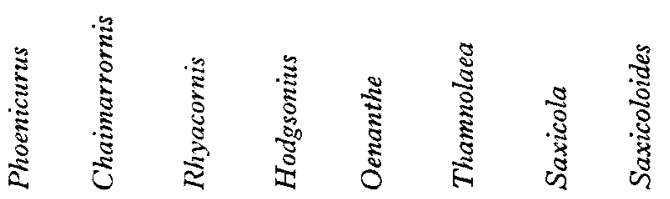

Tail rounded

Rufous on rectrices

Contrasting black terminal tail band

Contrasting dark central rectrices

White or pale crown patch

White patch on remiges

Sexual plumage dimorphism

\begin{tabular}{|c|c|c|c|c|c|c|c|}
\hline- & + & + & + & - & + & + & + \\
\hline$\pm^{\prime}$ & + & + & + & $\pm^{2}$ & - & - & - \\
\hline$!$ & + & - & + & \pm & - & - & - \\
\hline$\pm^{3}$ & - & - & + & + & - & - & - \\
\hline \pm & + & - & - & \pm & $\pm^{4}$ & - & - \\
\hline \pm & - & - & - & - & - & - & - \\
\hline 1 & - & + & + & + & + & + & $t$ \\
\hline
\end{tabular}

\footnotetext{
Notes: 1 All except $P$. caeruleocephalus.

${ }^{2} O$. moesta and $O$. xanthoprymna only.

${ }^{3}$ All except $P$. erythrogaster.

${ }_{4} T$. coronata only.
} 
but shorter than in the White-bellied Redstart Hodgsonius phaenicuroides. Size is in any case of lictle taxonomic value.

\section{Plumage}

Contra Goodwin (1957), the plumage patterns of male water redstarts show only a simplification of those of typical Phoenicurus spp. The only character common to the water redstarts and Thamnolaea spp. but not found in at least some Phoenicurus speciesa rounded, rather than square or notched, tail-is shared with Hodgsonius phaenicuroides (Table 1). Thamnolaea spp. differ from the water redstarts and all redstarts except the Blue-headed P. caeruleocephalus in lacking rufous on the rectrices.

Although no one redstart shares all of the plumage pattern features of a water redstart, each character occurs in at least one species of Phoenicurus. The Blue-fronted Redstart $P$. frontalis differs importantly from the White-capped Water Redstart only in its lighter hues, dark central rectrices and dark crown. The white crown of the White-capped contrasts with a dark forehead, as in $P$. erythrogaster and $P$. caeruleocephalus. In the White-crowned Cliff Chat Thamnolaea coronata and most white-capped wheatears (except for the White-crowned Black Wheatear O. l. leucopyga) white continues almost to or to the base of the bill. The absence of a white crown patch in Rhyacornis spp. does not disprove kinship with the White-capped Water Redstart. Such a patch is polymorphic within species of Oenanthe (Mayr \& Stresemann 1950).

\section{Sexual dimorphism}

Many genera (e.g., Pachycephala, Myzomela, Passer) include both dimorphic and monomorphic species. The sexes of White-capped Water Redstart are alike. The Philippine Water Redstart is only slightly dimorphic. The female Plumbeous Water Redstart has a grey back, scaly underparts and concealed white tail patches. This plumage resembles those of its immature and of immature redstarts and wheatears. As in immatures, the feathers of the underparts are pale, with (usually) two dark bands running parallel to or along their edges. The inner band may form a central spot. The derivation of this plumage from that of a redstart or wheatear immature requires only the loss of dorsal patterning, already much diminished in its immature, the replacement of brown by grey and the acquisition of white tail patches. Concealed tail patches occur in other thrush species whose congeners lack them (e.g., the White-tailed Stonechat Saxicola leucura, the White-tailed Robin Cinclidium leucurum).

\section{Ecology}

I observed the White-capped and Plumbeous Water Redstarts on fast-flowing streams, where they perched on emergent boulders. The White-capped also occurs on rocky slopes (Ludlow \& Kinnear 1937), as do many redstarts, wheatears and cliff chats. Phoenicurus erythrogaster is partly a stream bird (Meinertzhagen 1927, Schaefer 1938) and replaces the White-capped Water Redstart along streams at higher elevations (Ali \& Ripley 1973a). Oenanthe xanthoprymna may also occur on streams (Christison 1942). Choice of habitat does not provide taxonomic evidence in these cases (contra Desfayes 1969).

Although both the White-capped Water Redstart and Thamnolaea spp. nest in rock clefts or under eaves (Desfayes 1969), similar sites are used by the Plumbeous Water Redstart and many redstarts and wheatears (Ali \& Ripley 1973a,b, Harrison 1975). Goodwin (1957) used egg colour to separate Chaimarrornis and Rhyacornis from Phoenicurus. Lack (1958), however, concluded that intrageneric variation in egg colour rendered it valueless as a taxonomic character in the Turdinae. The White-throated Redstart Phoenicurus schisticeps has three distinct egg morphs (Ali \& Ripley 1973a). 
Voice

Desfayes (1969), citing written descriptions, claimed that the songs of the Whitecapped Water Redstart and Thamnolaea spp. are similar. The vocalizations of the water redstarts may, however, give little clue to their affinities. Call-notes I heard from both species in Kashmir - a shrill psweeeeee (White-capped), and a sharp prrt (Plumbeous), both easily heard over the rushing waters-resembled those of the other stream birds (cf. Orenstein 1975). Habitat choice may influence the evolution of vocalizations (Morton 1975). The noise of a torrent affects the carrying power of bird calls, and many stream birds have vocal repertoires of clear whistles, sharp shrill tones and other sounds able to penetrate this background (Orenstein MS). Differences between the calls of the two continental water redstarts may reflect their broad sympatry and habitat co-occupancy. The voice of the allopatric Philippine Water Redstart has not been described.

\section{Tail-wagging}

Ritualized tail movements are characteristic of the water redstarts. The White-capped Water Redstart wags its tail up and down through about $90^{\circ}$, most frequently upon alighting. The upward movement is the most marked. Plumbeous Water Redstarts dip the tail downwards, usually upon alighting, opening it on each downward stroke. In the female this reveals the white tail patches (pers. obs.). Almost nothing has been recorded about the Philippine Water Redstart. A presumed male was observed in Luzon by $M$. D. Bruce (in litt.): 'After each short flight and a few hops it paused for up to five seconds, in which time its tail was held at an angle of 45 degrees. Apart from this time and when in flight the tail was flicked up and down, especially so when it had just landed ... at which time it also dipped the tail downward and spread its rectrices from 1-3 times'. The bird was also seen 'flicking its tail downwards'. Cocking of the tail above the resting position is shared with the White-capped but not the Plumbeous Water Redstart. The absence of this component in the Plumbeous Water Redstart, like the differences in voice, may be of advantage for species recognition. Bruce (in litt.) observed tail cocking in Rhyacornis fuliginosus insularis of Taiwan, a race allopatric to the White-capped Water Redstart.

Tail-wagging and tail-flirting behaviours are widespread among smaller turdines, including Cinclidium, Cercomela, Saxicola, Saxicoloides, Monticola, Erithacus, Copsychus, Pinarochroa, Pentholaea, Cossypha, Dessonornis and Alethe as well as Phoenicurus, Oenanthe and Thamnolaea (Ali \& Ripley 1973a,b, Mackworth-Praed \& Grant 1963). Variation in such movement is, however, an unreliable generic character. The tail-wagging of the White-capped Water Redstart resembles that of Thamnolaea (Desfayes 1969) more than that of typical redstarts (Goodwin 1957). Some redstarts ( $P$. frontalis and Eversmann's Redstart $P$. erythronotus), however, have tail movements like that of the Whitecapped (Ali \& Ripley 1973a). Tail movement is widespread among stream-dwelling birds, and its presence in the water redstarts cannot be used as a clue to relationships (Orenstein 1975, MS).

\section{DISCUSSION}

The inclusion of the White-capped Water Redstart in Thamnolaea by Desfayes (1969) appears unwarranted. The White-capped Water Redstart is less similar to the cliff chats in plumage than it is to Phoenicurus frontalis, and resembles Thamnolaca more than it does Phoenicurus only in its rounded tail.

Most supposed dissimilarities among water and typical redstarts fall within the extremes of variation in Phoenicurus. Exceptions form minor modifications which do not increase the similarity of the water redstarts to Saxicola or Saxicoloides. The characters 
used by Desfayes (1969) to ally Rhyacornis and Oenanthe (e.g., flycatching, tail-wagging, nest site choice) do not adequately differentiate between redstarts and wheatears. Oenanthe, in fact, resembles Phoenicurus more than it does Saxicola. A diagnostic difference between the two genera-a greater culmen/tail ratio in wheatears (Seebohm 1881)seems trivial. Differences between wheatears and redstarts may reflect habitat and foraging technique.

Compared with the Plumbeous Water Redstart, the Philippine Water Redstart tends towards the White-capped in its larger size, generally darker colour, more extensively rufous underparts, relatively longer tail and reduced sexual dimorphism. Goodwin (1957) considered that the greyish-sepia, rather than chestnut, tail feathers of the female Philippine Water Redstart indicate that its female plumage developed from that of a Plumbeous Water Redstart-like ancestor independently of the White-capped. This reasoning assumes that reduction of sexual dimorphism is irreversible.

As the female plumage of the Plumbeous Water Redstart appears to be an independently-derived modification of its juvenile pattern, however, its evolution may represent a reacquisition of a lost sexual dimorphism. For instance, Williamson's Sapsucker Sphyrapicus thyroideus (Picidae) apparently evolved from a monomorphic ancestor, and its distinctive female plumage represents in part a reversion to a juvenal plumage similar to that of related genera (Short \& Morony 1970). Deriving both the White-capped and Plumbeous Water Redstarts from an ancestor similar to the Philippine Water Redstart assumes only that the loss of the original female plumage occurred before the loss of the redstart juvenile plumage in the White-capped. The two continental water redstarts are probably closely allied, with the Philippine species in some ways intermediate between them.

On the basis of plumage and, perhaps, tail-wagging behaviour, Phoenicurus frontalis is probably the species closest to the water redstarts. Their male plumages can be derived from that of $P$. frontalis with the development of a white cap in the White-capped Water Redstart, the loss of the terminal tail band in the Plumbeous and Philippine Water Redstarts, and the loss of dark pigment on the central rectrices. This last may bring the rounded tail into greater prominence during tail-wagging. Visual displays such as tailwagging are of increased importance for birds of rushing streams (Orenstein 1975, MS).

There appears, therefore, to be no evidence supporting the separation of Rhyacornis from Chaimarrornis, or of either genus from Phoenicurus. The Turdinae are badly in need of a modern multivariate taxonomic re-evaluation. Pending such a thorough study, however, I recommend that the three species of water redstart be included in the genus Phoenicurus. Their few special features may be viewed as an adaptation to the stream habitat. Specific nomenclature following this proposal would be: White-capped Water Redstart Phoenicurus leucocephalus, Plumbeous Water Redstart P. fuliginosus and Philippine Water Redstart P. bicolor.

Field observations were made during a trip with my parents, to whom I dedicate this paper in gratitude for their years of help and support. I am grateful to J. C. Barlow of the Royal Ontario Museum, Toronto, and R. W. Storer of the Museum of Zoology, University of Michigan, for providing access to the collections in their care. Further specimens were loaned by the American Museum of Natural History and National Museum of Natural History. I am indebted to M. D. Bruce for permission to quote from his field notes. R. W. Storer read and criticized the manuscript.

\section{REFERENCES}

Ali, S. \& Ripley, S. D. 1973a. Handbook of the Birds of India and Pakistan. Volume 8. Bombay: Oxford University Press.

Ali, S. \& Ripley, S. D. 1973b. Ibid., Volume 9.

Christison, A. F. P. 1942 . Some additional notes on the avifauna of northern Baluchistan. J. Bombay Nat. Hist. Soc. 43: 478-487.

Desfayes, M. 1969. Affinities of Chaimarrornis and Rhyacornis. Ibis 111 : 244-246.

DuPont, J. E. 1971. Philippine birds. Delaware Mus. Nat. Hist. Monogr. Ser. 2. 
Goodwin, D. 1957. Remarks on some genera of Turninae (sic). Bull. Br. Ornithol. Club 77: 110-113.

Hall, B. P. \& Moread, R. E. 1970. An atlas of speciation in African passerine birds. London: British Museum.

Harrison, C. J. 1975. A field guide to the nests, eggs and nestlings of British and European birds. London: Collins.

HarterT, E. 1910. Die Vögel der palaarktischen Fauna, 1. Berlin: Friedländer.

LACK, D. 1958. The significance of the colour of turdine eggs. Ibis 100:145-146.

Mackworth-Praed, C. W. \& Grant, C. H. B. 1963. Birds of the southern third of Africa, 2. London: Longmans.

Mayr, E. \& Stresemann, E. 1950. Polymorphism in the chat genus Oenanthe (Aves). Evolution 4: 291-300.

Meinertzhagen, R. 1927. Systematic results of birds collected at high altitudes in Ladak and Sikkim. Ibis $12: 571-633$.

Morton, E. 1975. Ecological sources of selection on avian sounds. Am. Nat. 109: 17-34.

ORENSTEIN, R. I. 1975. Observations and comments on two stream-adapted birds of Papua New Guinea. Bull. Br. Ornithol. Club 95: 161-165.

Orenstein, R. I. MS. Convergent evolution in stream-adapted birds.

Ripley, S, D. 1952. The thrushes. Postilla 13:1-48.

RiPLEY, S. D. 1962. Brief comments on the thrushes. Postilla $63: 1-5$.

Ripley, S. D. 1964. Subfamily Turdinae. In Mayr, E. \& Paynter, R. A. (eds), Peters' Check-list of the birds of the world, 10. Cambridge, Mass. : Museum of Comparative Zoology.

Schatfer, E. 1938. Ornithologische Ergebnisse zweier Forschungsreisen nach Tibet. J. Ornithol. 86 (Sonderh.): $1-349$.

Seевoнm, H. 1881. Catalogue of the birds in the British Museum, 5. London: British Museum.

Short, L. L. Jr. \& Morony, J. J. Jr. 1970. A second hybrid Williamson's $\times$ Red-naped Sapsucker and an evolutionary history of sapsuckers. Condor $72: 310-315$.

VAURIE, C. 1955. Systematic notes on Palaearctic birds, 14. Turdinae: the genera Erithacus, Luscinia, Tarsiger, Phoenicurus, Monticola and Oenanthe. Am. Mus. Nat. Hist. Novit. 1731.

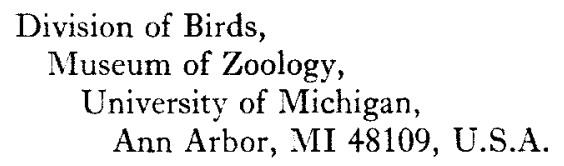

10 March 1978

RONALD I. ORENSTEIN

\section{SEX RATIOS AMONG THREE EUPLECTES SPECIES IN SOUTHERN AFRICA}

Polygyny is the predominant mating system among the savannah-dwelling African Ploceidae (Crook 1964), and it has been demonstrated for the Red Bishop Euplectes orix (Skead 1956, Craig 1974), the Red-collared Widow E. ardens (Van Someren 1956) and the Red-shouldered Widow E. axillaris (Skead 1959). It has been suggested that in polygynous species there is an excess of females in the population (discussed in Selander 1965). However, Verner (1964) found that in the Long-billed Marsh Wren Telmatodytes palustris unmated territorial males may be present while other males have several mates, and Orians (1961) demonstrated that there are numerous non-breeding males in the Red-winged Blackbird Agelaius phoeniceus.

Unfortunately, previous writers have based their cornments on the Euplectes species on the impressions of observers in the field, who have noted that in the flocks males in nuptial plumage were greatly outnumbered by brown-plumaged birds. Thus although Davies (1910) had reported that many of the 'browns' in flocks of Long-tailed Widows Euplectes progne were immature males, the myth of the male accompanied by a large harem has been perpetuated by recent authors (e.g., Mackworth-Praed \& Grant 1962). Mayr (1939) wrote of the Orange Bishop E. franciscanus and the Fire-crowned Bishop $E$. hordeaceus, ' . . it is well known that in these species the females outnumber the males at least 2:1'. Even Lack (1968) fell into the same trap, concluding from Moreau \& Moreau's (1938) figures of one male to six browns in the flocks that there is definitely a surplus of females in the Euplectes species.

We have investigated the sex ratio of the Red Bishop, Red-collared Widow and Red$0019-1019 / 79 / 020224+04 \$ 02.00 / 0$

(C) 1979 The British Ornithologists' Union 